\title{
THE HEMATOCRIT OF THE LESSER CIRCULATION IN MAN ${ }^{1,2}$
}

\author{
By LAWRENCE S. LILIENFIELD, RENATO D. KOVACH, PAUL A. MARKS, ${ }^{3}$ LEE \\ M. HERSHENSON,4 GERALD P. RODNAN,4 FRANKLIN G. EBAUGH, JR., ${ }^{5}$ \\ AND EDWARD D. FREIS \\ (From the Cardiovascular Research Laboratory, Georgetown University Medical Center, Wash- \\ ington, D. C., the Veterans Administration Hospital, Washington, D. C., and the \\ National Institute of Arthritis and Metabolic Diseases, National Institutes \\ of Health, Bethesda, Maryland)
}

(Submitted for publication October 3, 1955; accepted August 17, 1956)

A discrepancy appears to exist between total blood volume as calculated from albumin space and large vessel hematocrit, and total blood volume as calculated from red cell volume and this hematocrit $(1,2)$. The hematocrit as measured on arterial or venous blood indicates a ratio of red cell volume to plasma volume that is higher than the total body red cell volume to total body plasma volume ratio. Fahraeus (1) in 1921 performed experiments with blood flowing through fine glass capillaries in which he demonstrated a lower hematocrit in the fine capillaries than in the larger entrance or exit vessels. It was postulated that this phenomenon was due to laminar flow with axial streaming of red cells and consequent excess of plasma. Hence, the concept of a "small vessel or capillary hematocrit" was conceived.

Freis, Stanton and Emerson (3), using T-1824 dye and differential agglutination of red cells (Ashby technique), studied the transit times of plasma and red cells through the human forearm and found a more rapid circulation for red cells than for plasma. Lawson, Overbey, Moore and Shadle (4) studied the pulmonary circulation in dogs with T-1824 dye and $\mathrm{P}^{32}$ tagged red cells. These authors concluded that the hematocrit of the pulmonary capillaries was much lower than

\footnotetext{
1 Presented in part at the National Meeting of The American Federation for Clinical Research, Atlantic City, New Jersey, May 1, 1955.

2 Supported in part by the U. S. Public Health Service Grant H 1903 (National Heart Institute).

3 Present address: Department of Medicine, College of Physicians and Surgeons, Columbia University, New York.

4 Present address : Department of Medicine, University of Pittsburgh School of Medicine, Pittsburgh, $\mathrm{Pa}$.

5 Present address: Hitchcock Foundation, Hanover, New Hampshire.
}

that of the peripheral blood. Although Lawson's findings were consistent with a "small vessel hematocrit" concept, differences between methods used to measure red cell transit times and plasma transit times might well have affected his results.

Analysis of the data of Freis' experiments would indicate that the differences in transit times found were of insufficient magnitude to account for a lowering of the "small vessel hematocrit" by axial streaming of red cells. In an attempt to explore this phenomenon further, an investigation was made of the hematocrit of the pulmonary circulation in man.

\section{MATERIALS AND METHODS}

Eighteen studies were performed on thirteen patients without cardiovascular or pulmonary disease. Twenty ml. of a subject's blood was incubated for one hour at room temperature in a Fenwal bottle containing $9 \mathrm{ml}$. of N.I.H. Solution B acid citrate dextrose solution and approximately 50 to 100 microcuries of $\mathrm{Na}_{2} \mathrm{Cr}^{\mathrm{61}} \mathrm{O}_{4}$ equivalent to 25 to 200 micrograms of chromium metal. The mixture was centrifuged and the supernatant plasma removed. The bottle was then refilled with normal saline solution, mixed, recentrifuged and the saline supernatant removed. This was repeated until the washing saline was free of radioactivity. Twenty microcuries of $I^{m}$ tagged human serum albumin was then added with sufficient saline to reconstitute the suspension to $20 \mathrm{ml}$. After thorough mixing a portion of this suspension was removed for analysis. The remainder (approximately $5 \mathrm{ml}$.) was then injected rapidly with a calibrated syringe into the circulation of the subject. In eleven cases the injection was made into an antecubital vein and in seven cases into the main pulmonary artery through a cardiac catheter.

Samples of blood were collected continuously at twosecond intervals for one minute from a femoral artery through a seventeen gauge thin-wall needle via a short length of rubber tubing. The blood drained into paraffined test tubes containing one drop of dried heparin solution. Following collection of the samples, blood was taken for hematocrit determinations in Wintrobe tubes $(2,000 \mathrm{G}$ for 60 minutes). One or two $\mathrm{ml}$. samples of the re- 
TABLE I

Pulmonary blood flow from tagged red cells and tagged plasma albumin

\begin{tabular}{|c|c|c|c|c|c|c|c|}
\hline \multirow[b]{2}{*}{ Subject } & \multirow[b]{2}{*}{$\begin{array}{c}\text { Injection } \\
\text { site }\end{array}$} & \multirow[b]{2}{*}{ 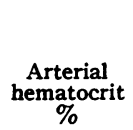 } & \multirow[b]{2}{*}{$\begin{array}{c}\text { Plasma } \\
\text { flow } \\
\text { ml. } / \text { sec. }\end{array}$} & \multirow[b]{2}{*}{$\begin{array}{c}\text { Red cell } \\
\text { flow } \\
\text { ml. } / \text { sec. }\end{array}$} & \multicolumn{2}{|c|}{ Total blood flow } & \multirow[b]{2}{*}{$\begin{array}{c}\text { Total flow } \\
\text { from RBC } \\
\text { Total flow } \\
\text { from plasma }\end{array}$} \\
\hline & & & & & 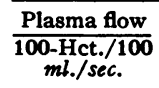 & $\frac{\text { Red cell flow }}{\begin{array}{c}\text { Hct. } / 100 \\
\text { ml. } / \mathrm{sec} .\end{array}}$ & \\
\hline $\begin{array}{l}\text { V. C. } \\
\text { W. W. } \\
\text { A. G. } \\
\text { E. B. } \\
\text { W. T. } \\
\text { R. B. } \\
\text { M. S. } \\
\text { J. M. } \\
\text { F. I. } \\
\text { J. P. } \\
\text { P. R. }\end{array}$ & $\begin{array}{l}\text { Ante- } \\
\text { cubital } \\
\text { vein }\end{array}$ & $\begin{array}{l}35.0 \\
41.6 \\
43.0 \\
41.4 \\
37.0 \\
39.0 \\
45.5 \\
44.0 \\
38.2 \\
44.5 \\
43.4\end{array}$ & $\begin{array}{r}53.9 \\
92.1 \\
56.2 \\
54.8 \\
170.5 \\
49.6 \\
46.1 \\
76.5 \\
57.6 \\
61.3 \\
95.7\end{array}$ & $\begin{array}{l}30.9 \\
65.0 \\
39.6 \\
38.5 \\
96.2 \\
35.5 \\
37.4 \\
63.5 \\
35.5 \\
45.0 \\
66.0\end{array}$ & $\begin{array}{r}82 \\
155 \\
99 \\
94 \\
271 \\
81 \\
84 \\
137 \\
93 \\
110 \\
169\end{array}$ & $\begin{array}{r}88 \\
156 \\
92 \\
93 \\
260 \\
91 \\
82 \\
144 \\
93 \\
102 \\
152\end{array}$ & $\begin{array}{r}1.07 \\
1.01 \\
.93 \\
.99 \\
.96 \\
1.12 \\
.98 \\
1.05 \\
1.00 \\
.93 \\
.90\end{array}$ \\
\hline $\begin{array}{l}\text { V. K. } \\
\text { L. J. } \\
\text { M. } \\
\text { J. M. } \\
\text { F. I. } \\
\text { J. P. } \\
\text { P. R. }\end{array}$ & $\begin{array}{c}\text { Pulmo- } \\
\text { nary } \\
\text { artery }\end{array}$ & $\begin{array}{l}43.0 \\
38.2 \\
45.5 \\
42.5 \\
38.2 \\
44.5 \\
42.8\end{array}$ & $\begin{array}{l}34.6 \\
62.4 \\
66.9 \\
69.3 \\
50.6 \\
60.1 \\
61.1\end{array}$ & $\begin{array}{l}26.7 \\
38.4 \\
52.9 \\
49.8 \\
32.0 \\
41.0 \\
50.1\end{array}$ & $\begin{array}{r}61 \\
101 \\
123 \\
121 \\
82 \\
106 \\
107\end{array}$ & $\begin{array}{r}62 \\
101 \\
116 \\
117 \\
84 \\
92 \\
117\end{array}$ & $\begin{array}{r}1.02 \\
1.00 \\
.94 \\
.97 \\
1.02 \\
.87 \\
1.09\end{array}$ \\
\hline Average & & & & & 115 & 113 & .99 \\
\hline S.D. & & & & & & & \pm .06 \\
\hline
\end{tabular}

maining blood were pipetted into vials and centrifuged. The supernatant plasma was removed and $0.5 \mathrm{ml}$. pipetted onto planchettes containing a few granules of dry detergent. The red cells remaining in the vials were washed three times with normal saline and the $\mathrm{Cr}^{51}$ activity of the erythrocytes determined in a scintillation well-type counter. $I^{12}$ activity of the plasma aliquots was determined with an end-window Geiger-Mueller tube after drying. A portion of the original injectate was analyzed in a similar manner. Because of high activity only $0.1 \mathrm{ml}$. aliquots were used for red cell activity measurement and Im activity of the supernatant was determined after dilution 1:250 times with saline. Counts of $\mathrm{Cr}^{51}$ were converted to counts per $\mathrm{ml}$. red cells from the hematocrit of the samples.

No correction for trapped plasma was made since

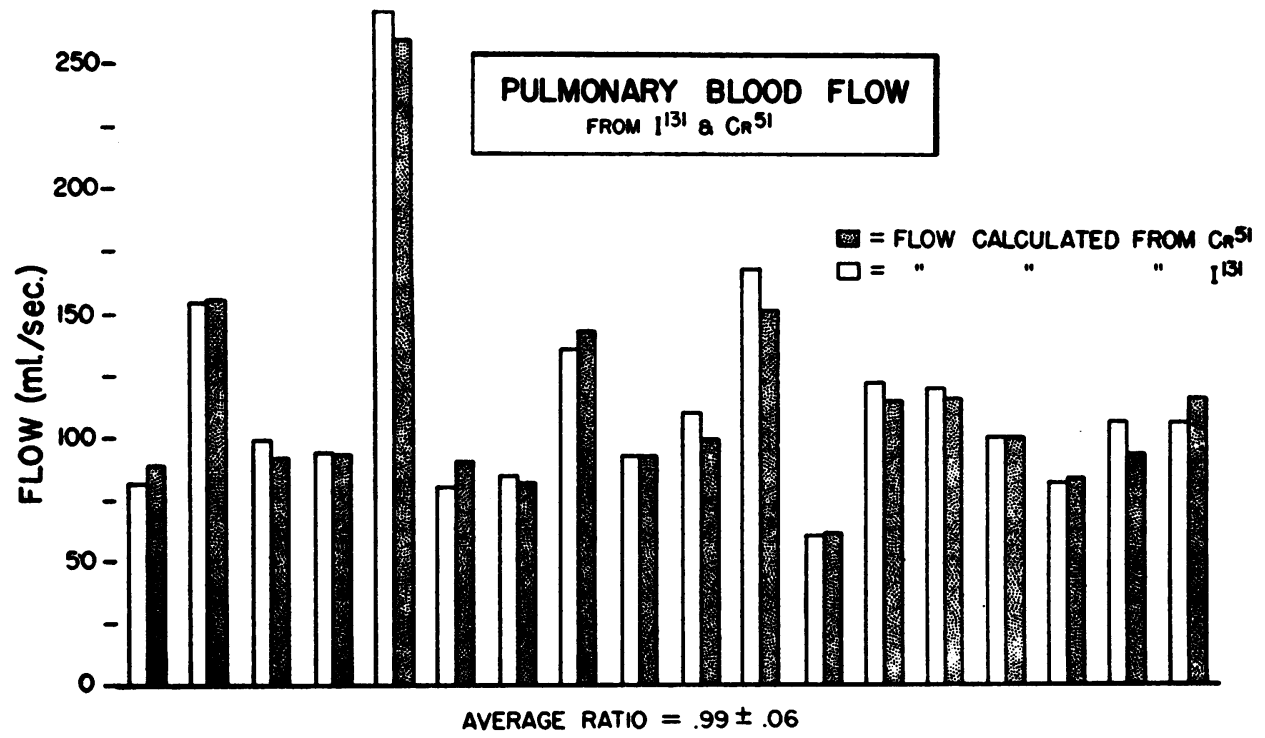

Fig. 1. Comparison of Pulmonary Blood Flow Calculated from large Vessel HematoCrit and Either Tagged Red Cells or Tagged Plasma 
TABLE II

Red cell and plasma volumes of central circulation (volume $=$ mean circulation time $\times$ flow)

\begin{tabular}{|c|c|c|c|c|c|c|c|c|c|}
\hline \multirow[b]{2}{*}{ Subject } & \multirow[b]{2}{*}{$\begin{array}{c}\text { Injection } \\
\text { site }\end{array}$} & \multicolumn{2}{|c|}{$\underset{\text { time }}{\text { Mean circulation }}$} & \multirow[b]{2}{*}{$\frac{T_{\text {rbo }}}{T_{p}}$} & \multirow[b]{2}{*}{$\begin{array}{c}\text { Red } \\
\text { cell } \\
\text { volume } \\
m l .\end{array}$} & \multirow[b]{2}{*}{$\begin{array}{c}\text { Plasma } \\
\text { volume } \\
\text { mb. }\end{array}$} & \multirow{2}{*}{ 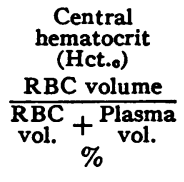 } & \multirow[b]{2}{*}{$\begin{array}{c}\text { Arterial } \\
\text { hema- } \\
\text { tocrit } \\
\text { (Hct..) } \\
\%\end{array}$} & \multirow[b]{2}{*}{$\frac{\text { Het. }}{\text { Het. }}$} \\
\hline & & $\begin{array}{c}\text { Red } \\
\text { cells } \\
\text { (Trbo) } \\
\text { sec. }\end{array}$ & $\begin{array}{c}\text { Plasma } \\
\text { albumin } \\
\left(T_{p}\right) \\
\text { sec. }\end{array}$ & & & & & & \\
\hline $\begin{array}{l}\text { V. C. } \\
\text { W. W. } \\
\text { A. G. } \\
\text { E. B. } \\
\text { W. T. } \\
\text { R. B. } \\
\text { M. S. } \\
\text { J. M. } \\
\text { F. I. } \\
\text { J. P. } \\
\text { P. R. }\end{array}$ & $\begin{array}{l}\text { Ante- } \\
\text { cubital } \\
\text { vein }\end{array}$ & $\begin{array}{l}18.8 \\
13.2 \\
17.4 \\
22.7 \\
10.2 \\
16.8 \\
31.6 \\
14.7 \\
25.8 \\
16.3 \\
18.4\end{array}$ & $\begin{array}{l}19.1 \\
13.1 \\
17.8 \\
23.8 \\
10.9 \\
17.6 \\
31.7 \\
15.0 \\
26.3 \\
16.9 \\
19.1\end{array}$ & $\begin{array}{r}.99 \\
1.01 \\
.98 \\
.95 \\
.94 \\
.95 \\
1.00 \\
.98 \\
.98 \\
.96 \\
.96\end{array}$ & $\begin{array}{r}581 \\
857 \\
687 \\
875 \\
981 \\
596 \\
1,182 \\
933 \\
916 \\
734 \\
1,214\end{array}$ & $\begin{array}{r}1,027 \\
1,204 \\
1,000 \\
1,304 \\
1,858 \\
837 \\
1,461 \\
1,148 \\
1,515 \\
1,036 \\
1,828\end{array}$ & $\begin{array}{l}36.4 \\
41.5 \\
40.7 \\
40.2 \\
34.6 \\
40.6 \\
44.7 \\
44.8 \\
37.7 \\
41.5 \\
43.2\end{array}$ & $\begin{array}{l}35.0 \\
41.6 \\
43.0 \\
41.4 \\
37.0 \\
39.0 \\
45.5 \\
44.0 \\
38.2 \\
44.5 \\
43.4\end{array}$ & $\begin{array}{r}1.04 \\
1.00 \\
.95 \\
.97 \\
.94 \\
1.04 \\
.98 \\
1.02 \\
.99 \\
.93 \\
1.00\end{array}$ \\
\hline Average & & 18.7 & 19.2 & .97 & 867 & 1,296 & & & .99 \\
\hline S.D. & & & & \pm .02 & & & & & \pm .04 \\
\hline $\begin{array}{l}\text { V. K. } \\
\text { L. J. } \\
\text { M. } \\
\text { J. M. } \\
\text { F. I. } \\
\text { J. P. } \\
\text { P. R. }\end{array}$ & $\begin{array}{l}\text { Pulmo- } \\
\text { nary } \\
\text { artery }\end{array}$ & $\begin{array}{l}11.6 \\
12.5 \\
15.5 \\
10.1 \\
13.7 \\
11.6 \\
11.5\end{array}$ & $\begin{array}{l}12.4 \\
13.0 \\
15.5 \\
10.3 \\
14.3 \\
12.3 \\
11.6\end{array}$ & $\begin{array}{r}.94 \\
.96 \\
1.00 \\
.98 \\
.96 \\
.94 \\
.99\end{array}$ & $\begin{array}{l}310 \\
480 \\
820 \\
502 \\
438 \\
476 \\
576\end{array}$ & $\begin{array}{r}429 \\
811 \\
1,037 \\
714 \\
724 \\
739 \\
708\end{array}$ & $\begin{array}{l}40.3 \\
35.5 \\
45.5 \\
45.9 \\
38.6 \\
39.2 \\
42.2\end{array}$ & $\begin{array}{l}43.0 \\
38.2 \\
45.5 \\
42.5 \\
38.2 \\
44.5 \\
42.8\end{array}$ & $\begin{array}{r}.94 \\
.93 \\
1.00 \\
1.08 \\
1.01 \\
.88 \\
.99\end{array}$ \\
\hline Average & & 12.4 & 12.8 & .97 & 515 & 737 & & & .98 \\
\hline S.D. & & & & \pm .02 & & & & & \pm .07 \\
\hline
\end{tabular}

the hematocrits of the injectate and the samples were determined in the same manner. The $\mathrm{Cr}^{\mathrm{s1}}$ counts were plotted logarithmically against time, zero time being designated as the midpoint of the interval required for injection (usually two to five seconds). After extrapolation of the downslope of the resultant curve, the pulmonary red cell flow and mean circulation time were calculated by application of the Stewart-Hamilton principle (5). Similarly, the $I^{13}$ counts were plotted and the plasma flow calculated, as well as the plasma albumin mean circulation time. The calculation of flow and mean circulation time from the curves was performed employing a method of mathematical integration to infinite time (6).

The red cell volume and plasma volume of the central circulation were computed applying the formula: volume equals mean circulation time multiplied by flow. The hematocrit of the lesser circulation was taken as the ratio of the red cell volume to the sum of the red cell volume plus plasma volume. Hematocrits also were calculated directly from the ratio of mean circulation times as discussed later.

\section{RESULTS}

Total blood flows calculated from either tagged red cells or plasma and the arterial hematocrit were almost identical (Table I, Figure 1). The ratio of these simultaneously but independently measured flows was .99 (S.D. \pm .06 ).

The circulating red cell volumes, plasma volumes and the hematocrits of the lesser circulation are tabulated in Table II. The upper portion of the table refers to the data obtained following antecubital vein injections; the lower portion refers to the data obtained following pulmonary injection. The ratio of central circulation to large vessel hematocrit averaged .99 \pm .04 (S.D.) following peripheral injection and $.98 \pm .07$ (S.D.) following central injection. This table also indicates the mean circulation time for red cells and plasma from each injection site. In both series the ratio of red cell to plasma mean transit times averaged $.97 \pm .02$ (S.D.), a figure not significantly different from unity $(P>.05)$.

The total circulating central blood volumes (red cell plus plasma volumes) measured by antecubital vein injection averaged $2,163 \mathrm{ml}$. as compared to $1,252 \mathrm{ml}$. following pulmonary artery injection. 
TABLE III

Red cell and plasma volumes calculated from extrapolated downslopes of plotted curves following antecubital vein injection (volume $=$ flow per downslope)

\begin{tabular}{lrrrr}
\hline \hline & \multicolumn{2}{c}{ 1/Downslope } & & \\
\cline { 2 - 5 } Subject & $\begin{array}{c}\text { Red } \\
\text { cells } \\
\text { sec. }\end{array}$ & $\begin{array}{c}\text { Plasma } \\
\text { albumin } \\
\text { sec. }\end{array}$ & $\begin{array}{c}\text { Red cell } \\
\text { volume } \\
\text { ml. }\end{array}$ & $\begin{array}{c}\text { Plasma } \\
\text { volume } \\
\text { ml. }\end{array}$ \\
\hline V. C. & 10.5 & 10.8 & 324 & 579 \\
W. W. & 4.8 & 4.2 & 312 & 387 \\
A. G. & 6.4 & 6.5 & 253 & 365 \\
E. B. & 8.3 & 8.5 & 320 & 466 \\
W. T. & 3.1 & 3.3 & 298 & 566 \\
R. B. & 3.8 & 4.1 & 135 & 203 \\
M. S. & 10.2 & 10.0 & 381 & 461 \\
J. M.* & 4.7 & 4.6 & 298 & 352 \\
F. I.* & 7.9 & 7.8 & 279 & 446 \\
J. P.* & 3.7 & 4.0 & 167 & 245 \\
P. R. & 4.8 & 4.4 & 317 & 416 \\
Average & & & 280 & 408 \\
\hline
\end{tabular}

- Subjects also had measurements made following pulmonary artery injection. See Table IV.

The large volume after antecubital vein injection can be explained by the fact that it includes the venous volume from the site of injection and all possible equitemporal injection sites.

"Pulmonary" volumes were also calculated from the extrapolated downslopes of the plotted curves according to the method described by Newman, Merrell, Genecin, Monge, Milnor and McKeever (7). The average total "pulmonary" blood volume measured $688 \mathrm{ml}$. following antecubital vein injection and $231 \mathrm{ml}$. following pulmonary artery injections (Tables III and IV). The possibility exists that this difference resulted from incomplete mixing of the indicators with pulmonary artery blood when injected through the catheter. Under this condition only a portion of the pulmonary blood volume would be measured. However, this marked difference in apparent pulmonary blood volume as measured by the Newman technique includes in the group five patients who had successive determinations made from both injection sites. In each of these five cases, the volume measured following antecubital vein injection was two and one-half to three times that calculated following pulmonary artery injection. It would seem unlikely that incomplete mixing, which should give random results, could account for the fairly constant relationship observed. Similar changes in downslope with varying injection sites, under conditions in which incomplete mixing was more probably not a factor, have been reported by Hetzel, Swan and Wood in an even larger number of patients (8). It is more likely that, under conditions of peripheral injection, the largest volume in the series through which the indicators are diluted includes the venous system and perhaps the right heart. Hence, the slope following peripheral injection would measure this volume rather than that of the lung. On the assumption that the slope following pulmonary artery injection measures pulmonary volume, the hematocrit of this "pulmonary" vasculature was calculated. The ratio of "pulmonary" to large vessel hematocrit again in these cases averaged .98 (S.D. \pm .05 ) (Table IV, Figure 2).

TABLE IV

"Pulmonary" red cell and plasma volumes and "pulmonary" hematocrit following pulmonary artery injection (from volume $=$ flow per downslope)

\begin{tabular}{|c|c|c|c|c|c|c|c|}
\hline \multirow[b]{2}{*}{ Subject } & \multicolumn{2}{|c|}{ 1/Downslope } & \multirow[b]{2}{*}{$\begin{array}{c}\text { Red } \\
\text { cell } \\
\text { volume } \\
\text { ml. }\end{array}$} & \multirow[b]{2}{*}{$\begin{array}{l}\text { Plasma } \\
\text { volume } \\
m l .\end{array}$} & \multirow[b]{2}{*}{$\begin{array}{c}\text { "Pulmonary" } \\
\text { hematocrit } \\
\%\end{array}$} & \multirow[b]{2}{*}{$\underset{\%}{\substack{\text { Arterial } \\
\text { hematocrit }}}$} & \multirow[b]{2}{*}{$\frac{\text { Pulm. Het. }}{\text { Art. Het. }}$} \\
\hline & $\begin{array}{l}\text { Red } \\
\text { cells } \\
\text { sec. }\end{array}$ & $\begin{array}{c}\text { Plasma } \\
\text { albumin } \\
\text { sec. }\end{array}$ & & & & & \\
\hline $\begin{array}{l}\text { V. K. } \\
\text { L. J.ं } \\
\text { M.S.* } \\
\text { J. M.* } \\
\text { F. I.* } \\
\text { J. P.* } \\
\text { P. R.* }\end{array}$ & $\begin{array}{l}2.4 \\
2.0 \\
2.9 \\
2.0 \\
2.7 \\
2.4 \\
1.9\end{array}$ & $\begin{array}{l}2.8 \\
2.3 \\
2.7 \\
1.8 \\
2.7 \\
2.3 \\
2.1\end{array}$ & $\begin{array}{r}64 \\
77 \\
151 \\
100 \\
86 \\
106 \\
93\end{array}$ & $\begin{array}{r}95 \\
140 \\
181 \\
118 \\
137 \\
138 \\
128\end{array}$ & $\begin{array}{l}40.3 \\
35.5 \\
45.5 \\
45.9 \\
38.6 \\
43.4 \\
42.2\end{array}$ & $\begin{array}{l}43.0 \\
38.2 \\
45.5 \\
42.5 \\
38.2 \\
44.5 \\
42.8\end{array}$ & $\begin{array}{r}.94 \\
.93 \\
1.00 \\
1.08 \\
1.01 \\
.98 \\
.98\end{array}$ \\
\hline Average & 2.33 & 2.39 & 97 & 134 & & & .98 \\
\hline S.D. & & & & & & & \pm .05 \\
\hline
\end{tabular}

\footnotetext{
* Subjects also had measurements made following antecubital vein injection. See Table III.
} 


\section{"PULMONARY" HEMATOCRIT VS LG. VESSEL HEMATOCRIT} PULMONARY ARTERY INJECTION OF INOICATOR

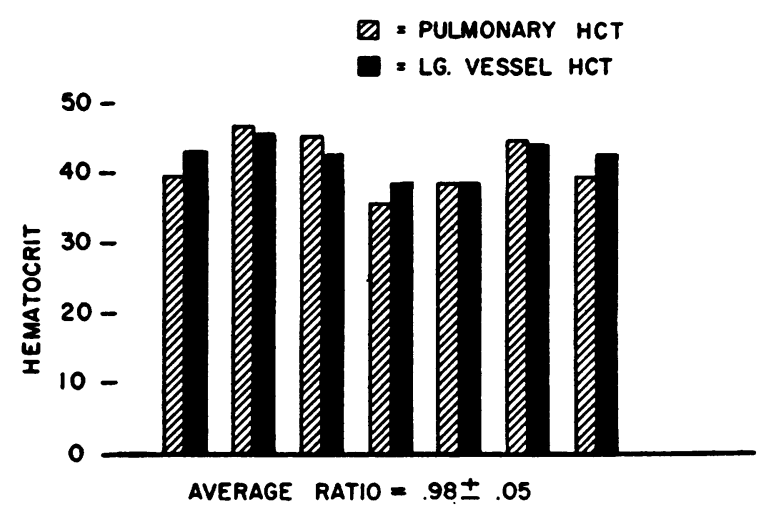

Fig. 2. Comparison of Hematocrits Calculated from "Pulmonary" Volume Measurements (Newman Method) With Large Vessel. Hematocrits in Seven Subjects

\section{DISCUSSION}

These data demonstrate that during one circulation there is no measurable loss of tracer albumin by this method in the pulmonary capillaries. Had there been utilization, the total blood flow as calculated from tagged albumin would have been significantly higher than the total blood flow as calculated from the tagged red cells. Since the calculated blood flows are essentially identical the hematocrit of the lesser circulation can be recalculated directly from the ratio of mean circulation time of red cells to mean circulation time of plasma albumin as follows :

$$
\mathrm{V}_{\mathrm{rbc}}=\mathrm{F}_{\mathrm{rbc}} \times \mathrm{T}_{\mathrm{rbc}}
$$

and

$$
\mathrm{V}_{\mathrm{pl}}=\mathrm{F}_{\mathrm{pl}} \times \mathrm{T}_{\mathrm{pl}}
$$

where $V, F$, and $T$ represent volume, flow and mean circulation time of red cells (rbc) and plasma (pl).

The central hematocrit $\left(H_{c}\right)$ then is given by

$$
H_{c}=\frac{V_{r b c}}{V_{r b c}+V_{p l}}=\frac{F_{r b c} \times T_{r b c}}{F_{r b c} \times T_{r b c}+F_{p l} \times T_{p 1}}
$$

Since values of total pulmonary blood flow calculated on the basis of the large vessel hematocrit $\left(\mathrm{H}_{1 \mathrm{v}}\right)$ and the distribution of tagged red cells, or tagged plasma protein, are identical,

$$
\frac{F_{r b c}}{H_{l v}}=\frac{F_{p l}}{1-H_{l v}}
$$

or by rearrangement,

$$
\frac{F_{r b c}}{F_{p l}}=\frac{H_{l v}}{1-H_{1 v}}
$$

Substituting (5) into (3), and after rearrangement, we now have

$$
H_{c}=\frac{\frac{T_{\text {rbo }}}{T_{p 1}}}{\frac{T_{r b c}}{T_{p 1}}+\frac{1-H_{l v}}{H_{l v}}}
$$

When the central circulation hematocrits calculated from equation six are compared to the large vessel hematocrits, the ratio again averages .98 (S.D. \pm .01 ) following antecubital vein injection and .98 (S.D. \pm .02 ) following pulmonary artery injection. The chief advantage of this method of calculation is that it eliminates the need for analysis of the injectate and thus reduces a possible source of laboratory error.

Similar reasoning can be applied in determining the hematocrit of the "pulmonary" circulation directly from the measured downslopes of the extrapolated curves without blood flow calculation. By this method the "pulmonary" hematocrit averages $.98 \pm .06$ (S.D.) (Table V).

In drawing conclusions from these data it is necessary to be aware of certain limitations inherent in the method used in this study. Volumes measured by mean transit times must in- 
TABLE V

"Pulmonary" hematocrit as calculated directly from extrapolated red cell and plasma time concentration curve downslopes following pulmonary artery injection

\begin{tabular}{|c|c|c|c|c|c|c|}
\hline \multirow[b]{2}{*}{ Subject } & \multicolumn{2}{|c|}{ 1/Downslope } & \multirow[b]{2}{*}{$\frac{S_{r}}{S_{p}}$} & \multirow[b]{2}{*}{$\begin{array}{c}\text { Pulmonary } \\
\text { hematocrit } \\
\%\end{array}$} & \multirow[b]{2}{*}{$\begin{array}{c}\text { Arterial } \\
\text { hematocrit } \\
\% \%\end{array}$} & \multirow[b]{2}{*}{$\frac{\text { Pulm. Hct. }}{\text { Art. Hct. }}$} \\
\hline & $\begin{array}{l}\text { Red } \\
\text { cells } \\
\left(S_{\mathrm{r}}\right) \\
\text { sec. }\end{array}$ & $\begin{array}{c}\text { Plasma } \\
\text { albumin } \\
\left(\mathbf{S}_{\mathrm{p})}\right) \\
\text { sec. }\end{array}$ & & & & \\
\hline $\begin{array}{l}\text { V. K. } \\
\text { L. J. } \\
\text { M.S. } \\
\text { J. M. } \\
\text { F. I. } \\
\text { J. P. } \\
\text { P. R. }\end{array}$ & $\begin{array}{l}2.4 \\
2.0 \\
2.9 \\
2.0 \\
2.7 \\
2.4 \\
1.9\end{array}$ & $\begin{array}{l}2.8 \\
2.3 \\
2.7 \\
1.8 \\
2.7 \\
2.3 \\
2.1\end{array}$ & $\begin{array}{r}.86 \\
.87 \\
1.07 \\
1.11 \\
1.00 \\
1.04 \\
.90\end{array}$ & $\begin{array}{l}39.3 \\
34.9 \\
47.1 \\
45.1 \\
38.2 \\
45.4 \\
40.2\end{array}$ & $\begin{array}{l}43.0 \\
38.2 \\
45.5 \\
42.5 \\
38.2 \\
44.5 \\
42.8\end{array}$ & $\begin{array}{r}.91 \\
.91 \\
1.04 \\
1.06 \\
1.00 \\
1.02 \\
.94\end{array}$ \\
\hline Average & 2.33 & 2.39 & .97 & & & .98 \\
\hline S.D. & & & & & & \pm .06 \\
\hline
\end{tabular}

clude the blood contained in all the vessels from the injection site and all possible equitemporal injection sites to the sampling site and all possible equitemporal sampling sites. Thus, the hematocrit measured, especially following peripheral vein injection, is the average hematocrit of blood in the great vessels, heart, and the pulmonary capillaries. This amount of large vessel blood would be expected to partially mask any effect on the measured hematocrit of the blood contained in the pulmonary capillaries. Much of this large vessel blood can be eliminated from the measurement by injecting the indicators into the pulmonary artery. Though there is the possibility that mixing in the pulmonary artery is incomplete, this probably has no bearing on the hematocrit results. The albumin and red cells are well mixed before injection and should therefore have the same opportunities with respect to their pathways through the lung. Incomplete mixing with pulmonary artery blood can only result in measurement of the hematocrit of a portion, rather than the whole, of the pulmonary capillary bed. It would seem reasonable, however, that results obtained in a part of the lung would be representative of its entire capillary bed.

The average volume measured by antecubital vein injection was $2163 \mathrm{ml}$. compared to an average of $1252 \mathrm{ml}$. by pulmonary artery injection (Table II). In spite of this elimination of about $900 \mathrm{ml}$. of large vessel blood the ratios of the mean transit times for red cells and plasma remained identical $(.97 \pm .02)$, as did the calculated hematocrit ratios (.98 \pm .02$)$ (Figure 3 ). Neither of these ratios is statistically different from unity $(P>.05)$, and their failure to change with injection site indicates that the circulating pulmonary hematocrit is not significantly different from the hematocrit of the larger entrance or exit vessels. The tabulated change in ratio of central hematocrit to large vessel hematocrit with injection site shown in Table II (from .99 \pm .04 to $.98 \pm .07)$ is an artefact introduced by the statistical variations in blood flow measurement. This has been eliminated, as explained previously, in the construction of Figure 3 .

These data would indicate, therefore, that in the pulmonary capillary bed of man no significant degree of axial streaming of red cells can be demonstrated by this method, and that the pulmonary capillary hematocrit, as measured by mean transit time single circulation techniques, is not significantly different from the large vessel hematocrit. Similar experiments in this laboratory utilizing the human forearm capillary beds have also failed to show evidence of significant red cell streaming in its component organs (9).

If then, as these studies suggest, red cells and plasma have the same relative volume of distribution in a single circulation in the lungs and forearm capillary beds as they do in the larger blood vessels, how can the apparent excess of plasma albumin space as measured by total body plasma volume determinations be explained? Studies of the splanchnic area in man in this laboratory (10) and independently by Lathem and Gordon (11) by an equilibration method (12), have shown a splanchnic to large vessel hematocrit ratio also of about .91. This in itself would not be sufficient 


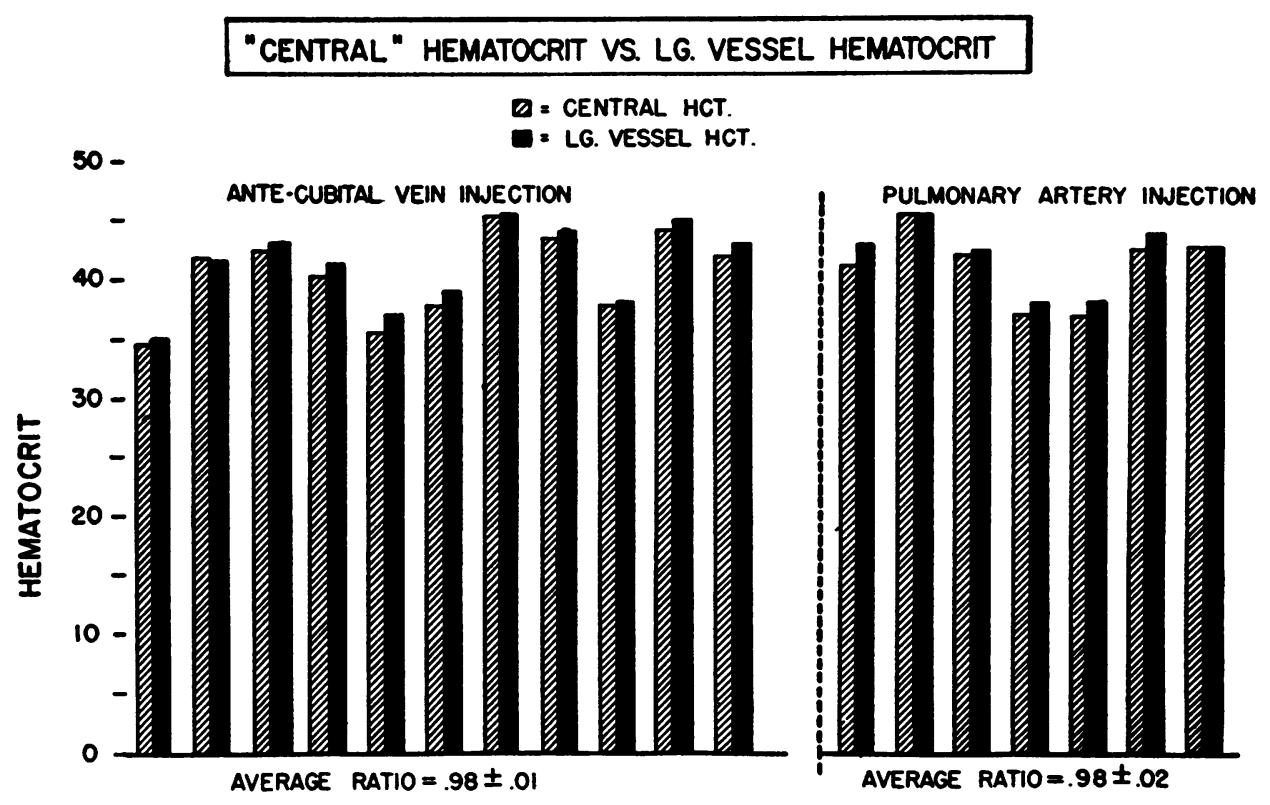

Fig. 3. Central Hematocrits Determined by Measurement of Mean Circulation Time Compared with Large Vessel Hematocrits in Eighteen Studies

to account for the total body plasma albumin excess. The most likely explanation follows from an analysis of the methods used in the various studies. Since total body plasma measurements and splanchnic plasma volume studies require several minutes for equilibration, it seems likely that there exists a slowly circulating albumin space, either extravascularly or in intermittently closed capillaries containing trapped plasma, which equilibrates over several minutes with tagged albumin, and which is not measured by single circulation techniques. The observations of Rapaport, Kuida, Haynes and Dexter (13) in studying the pulmonary blood volume in dogs by both single circulation and equilibration methods would support this concept.

Another possibility to be considered is that albumin entering a capillary might not diffuse into a layer of slow moving plasma lining the capillary wall during a single circulation. The rate of mixing of entering albumin with this circumferential layer of plasma will depend upon the rate of diffusion of albumin in flowing plasma. Since albumin is of relatively large molecular size, its rate of diffusion is less than that of the smaller crystalloids and might be sufficiently small to prevent complete exchange with the circumferential layer of plasma albumin during a single circulation.
Under these circumstances, the method used in this study would not be expected to measure the volume of this lining of plasma.

Failure of complete exchange of intravascular albumin does not seem likely, however, from the following consideration: if there were critical differences in mixing, due to variations in diffusion characteristics of substances of different molecular size, one would expect that small molecules would exhibit more complete exchange with the circumferential plasma layer than larger protein molecules. If this were the case the mean circulation time of albumin during a single circulation would be significantly less than that of smaller crystalloids. However, in studies of the central circulation the mean transit times of thiocyanate ion (14) and ionic $\mathrm{Na}^{24}$ (15) have been found to be identical with simultaneously injected labelled albumin and hence must have the same intravascular volume of distribution as the albumin. It would seem then to be valid to assume at this time that, during a single circulation, albumin mixes with all the plasma contained in a capillary into which it enters.

\section{SUMMARY AND CONCLUSION}

Red cell and plasma flows, mean circulation times, and indicator dilution curve downslopes 
were simultaneously but independently measured in the lesser circulation in normal human subjects using $\mathrm{Cr}^{51}$ tagged red cells and $\mathrm{I}^{131}$ tagged albumin. Hematocrits of the lesser circulation and "pulmonary" capillaries were calculated from the data and compared to the arterial hematocrit measured in Wintrobe tubes. The ratio of lesser circulation to large vessel hematocrits averaged $.98 \pm .02$ (S.D.). The results suggest that axial streaming of red cells in the lung capillaries does not occur to any significant extent.

\section{ACKNOWLEDGMENTS}

The authors gratefully acknowledge the valuable technical assistance of Miss Jean Pietras, Mrs. Irma Kranzler, and Mrs. Elizabeth Marsden.

\section{REFERENCES}

1. Fahraeus, R., The suspension stability of the blood. Physiol. Rev., 1929, 9, 241.

2. Barnes, D. W. H., Loutit, J. F., and Reeve, E. B., A comparison of estimates of circulating red blood cell volume given by the Ashby marked red cell method and $T$ 1824-hematocrit method in man. Clin. Sc., 1948, 7, 135.

3. Freis, E. D., Stanton, J. R., and Emerson, C. P., Estimation of relative velocities of plasma and red cells in the circulation of man. Am. J. Physiol., 1949, 157, 153.

4. Lawson, H. C., Overbey, D. T., Moore, J. C., and Shadle, O. W., Mixing of cells, plasma and dye T-1824 in cardiovascular system of barbitalized dogs. Am. J. Physiol., 1947, 151, 282.

5. Hamilton, W. F., Moore, J. W., Kinsman, J. M., and Spurling, R. G., Studies on the circulation. IV. Further analysis of injection method, and of changes in hemodynamics under physiological and pathological conditions. Am. J. Physiol., 1932, 99, 534.
6. Lilienfield, L. S., and Kovach, R. D., Simplified method for calculating flow, mean circulation time and downslope from indicator-dilution curves. Proc. Soc. Exper. Biol. \& Med., 1956, 91, 595.

7. Newman, E. V., Merrell, M., Genecin, A., Monge, C., Milnor, W. R., and McKeever, W. P., The dye dilution method for describing the central circulation. Circulation, 1951, 4, 735.

8. Hetzel, P. S., Swan, H. J. C., and Wood, E. H., Influence of injection site on arterial dilution curves of T-1824. J. Applied Physiol., 1954, 7, 66.

9. Lilienfield, L. S., Kovach, R. D., and Freis, E. D., Similarity between the large vessel and forearm "capillary" hematocrits as determined by the single circulation indicator dilution technics. (Abst.) Circulation, 1955, 12, 741.

10. Hershenson, L. M., Marks, P. A., Lilienfield, L. S., Rodnan, G. P., Kovach, R. D., Ebaugh, F. G., Jr., and Freis, E. D., Splanchnic hematocrit in man. In preparation.

11. Lathem, W., and Gordon, M. E., The circulating splanchnic red blood cell and plasma volumes and the splanchnic hematocrit in man. (Abst.) Clinical Research Proceedings, 1955, 3, 37.

12. Bradley, S. E., Marks, P. A., Reynell, P. C., and Meltzer, J., The circulating splanchnic blood volume in dog and man. Tr. A. Am. Physicians, 1953, 66, 294.

13. Rapaport, E., Kuida, H., Haynes, F. W., and Dexter, L., The influence of the pulmonary hematocrit on the determination of the circulating pulmonary blood volume. (Abst.) Clinical Research Proceedings, 1955, 3, 110.

14. Lilienfield, L. S., Freis, E. D., Partenope, E. A., and Morowitz, H. J., Transcapillary migration of heavy water and thiocyanate ion in the pulmonary circulation of normal subjects and patients with congestive heart failure. J. Clin. Invest., 1955, 34, 1.

15. Kovach, R. D., Lilienfield, L. S., Hershenson, L., and Freis, E. D., Transcapillary migration of radioactive sodium ${ }^{*}$ through the pulmonary and forearm capillary beds of man. (Abst.) Circulation, 1955, 12, 734. 